\title{
Trophic niche of Dendropsophus minutus (Anura: Hylidae) in southern Brazil
}

\author{
Peterson T. Leivas, ${ }^{1}$ Thiago B. Mayer, ${ }^{1}$ Fernando W. T. Leivas, ${ }^{2}$ and Luis F. Fávaro ${ }^{1}$ \\ ${ }^{1}$ Universidade Federal do Paraná (UFPR), Centro Politécnico, Pós-Graduação em Zoologia. Av. Coronel Francisco Heráclito \\ dos Santos 210, Jardim das Americas, Caixa postal 19020, CEP 81531-970, Curitiba, PR, Brazil. E-mail: ptleivas@gmail. \\ com. \\ ${ }^{2}$ Universidade Federal do Paraná (UFPR), Setor Palotina, Departamento de Biodiversidade. Rua Pioneiro 2153, Jardim Dallas, \\ CEP 85950-000, Palotina, PR, Brazil.
}

\begin{abstract}
Trophic niche of Dendropsophus minutus (Anura: Hylidae) in southern Brazil. The feeding biology of the Neotropical tree frog Dendropsophus minutus is described based on identification of the items consumed by the anuran. Samples were collected monthly samplings for one year in an Araucaria forest in the state of Paraná in southern Brazil. Of the total of 101 gastrointestines examined, 51 were empty or contained digested remains or plant items. The 50 samples of gastrointestinal contents contained three classes and 10 orders of arthropods. The results suggest that $D$. minutus is a generalist predator that feeds on arthropods, primarily those in the orders Araneae, Lepidoptera, and Diptera. The diet varies seasonally depending upon prey activity, which determines the breadth of the trophic niche of the frog.
\end{abstract}

Keywords: Araucaria forest, amphibian ecology, diet, predation, prey.

\begin{abstract}
Resumo
Nicho trófico de Dendropsophus minutus (Anura: Hylidae) no sul do Brasil. A biologia alimentar da perereca neotropical Dendropsophus minutus é descrita a partir da identificação dos itens predados pela espécie. Amostras foram coletadas mensalmente por um ano em uma área de Floresta de Araucária no estado do Paraná, sul do Brasil. Um total de 101 estômagos foi analisado, sendo que desses 51 estavam vazios ou continham itens digeridos ou fragmentos de plantas. As 50 amostras de conteúdo gastrintestinais estudadas continham três classes e 10 ordens de artrópodes. Os resultados sugerem que $D$. minutus é um predador generalista que se alimenta de artrópodes, principalmente das ordens Araneae, Lepidoptera e Diptera. A dieta varia sazonalmente, dependendo da atividade das presas, o que determina a amplitude do nicho trófico da espécie.
\end{abstract}

Palavras-chave: dieta, ecologia de anfíbios, Floresta com Araucária, predação, presa.

Received 02 February 2018

Accepted 29 May 2018

Distributed December 2018 


\section{Introduction}

The adults and juveniles of most anuran species are generalist predators of invertebrates and vertebrates (Toledo et al. 2007, López et al. 2009). However, some taxa, such as poison-dart frogs of the genus Dendrobates (Wagler, 1830), have specialized diets (e.g., Toft 1995). Irrespective of the type of diet (i.e., generalist or specialist), anurans occupy an important trophic position in terrestrial and aquatic ecosystems because they are predators invertebrates, as well as prey of vertebrates and invertebrates (Toledo et al. 2007, Wells 2007).

Anuran diets may be determined by behavioral factors (Maneyro et al. 2004, Toledo et al. 2007), morphological characteristics of the predator and/or prey (e.g., prey size or predator mouth size; Biavati et al. 2004, Toledo et al. 2007, Pacheco et al. 2017), or by the period of predator and/or prey activity (Leivas et al. 2012a); thus, study of their dietary habits is complex (López et al. 2009). The temporal variation of dietary resources associated with the physiological demands of anurans, such as energy for growth and reproduction (Grayson et al. 2005, Leivas et al. 2012b), may generate seasonal patterns in their diets (Miranda et al. 2006, Berazategui et al. 2007, Leivas et al. 2012a).

Male and female anurans have different energetic demands; therefore, there are differences in the diets of the sexes (Wells 2007). Males expend considerable energy in vocalization and territorial activities (Giasson and Haddad 2006, Wells 2007, Leivas et al. 2012b), whereas females use much of their energy to produce and develop oocytes (Wells 2007, Leivas et al. 2012a, Castro et al. 2013).

Dendropsophus minutus (Peters, 1872) is a small neotropical tree frog that is broadly distributed from Trinidad in the north of South America through Uruguay and Argentina in the south (Frost 2017). The species usually is abundant where it occurs and occupies natural, as well as anthropogenic, environments. Most autecological studies of $D$. minutus have focused on reproductive biology (Santos and Oliveira 2007, Santos et al. 2012, Leivas et al. 2018), behavioral traits (Morais et al. 2012), and habitat usage (Maffei et al. 2011).

Dietary studies of Dendropsophus minutus are scarce and restricted to a few localities in the northern and northeastern regions of Brazil (Van Sluys and Rocha 1998, Santos et al. 2004). They do not explore the seasonal aspects of diet, the trophic niche of the species, or the regional variations, topics that we address by describing the diet of the species, and analysis of the breadth of the trophic niche and seasonal variation in prey selection.

\section{Materials and Methods}

The study was conducted in Campina Grande do Sul, state of Paraná, Brazil $\left(25^{\circ} 17^{\prime} 09^{\prime \prime} \mathrm{S}\right.$, $49^{\circ} 00^{\prime} 05^{\prime \prime} \mathrm{W}$; $918 \mathrm{~m}$ a.s.l.). The vegetation is classified as Mixed Ombrophilous Mountainous Forest (Araucaria forest) and the climate is temperate $\mathrm{Cfb}$ following Koppen's classification (Peel et al. 2007). The sampling sites are two permanent ponds with floating vegetation. The area has of anthropogenic disturbance.

Samples were collected each month from January to December 2012 at night; two persons spent $3 \mathrm{hr}$ using acoustic and visual survey methods to search for frogs (Crump and Scott Jr. 1994). After capture, specimens were transported immediately to the laboratory and euthanized following current guidelines of the Conselho Federal de Biologia (CFBIO-Resolution 308). Voucher specimens are deposited at the Museu de História Natural do Capão da Imbuia, Curitiba, Paraná, Brazil.

We measured the snout-vent length (SVL) of each frog with digital calipers $(\mathrm{mm})$ and the body mass $(\mathrm{BM})$ with a precision balance $(0.001$ $\mathrm{g})$. The specimens were sectioned ventrally for the extraction of gastrointestinal contents. Prey items were quantified and identified (to the lowest possible taxonomic level) under stereoscope microscope. The body mass of each prey 
was measured with a precision balance $(0.001$ $\mathrm{g})$. The diet of specimens of $D$. minutus was not differentiated according to sex and to the ontogenetic stage.

The composition of gastrointestinal contents was quantified by calculating the frequency of occurrence $(\mathrm{FO})$ from $\mathrm{FO}=e i / \mathrm{E}$, where $e i=$ number of stomachs with item $i$, and $\mathrm{E}=$ total number of stomachs analyzed. The numerical frequency $(\mathrm{NF})$ was calculated from $\mathrm{NF}=n i / N$, where $n i=$ the number of prey items $i$ in all stomachs, and $N=$ total number of items found in all stomachs. Prey weight (PW) was calculated from $\mathrm{P}=p i / \mathrm{P}$, where $p i=$ weight of item $i$ in all stomachs, and $\mathrm{P}=$ weight of all items in all stomachs. The index of relative importance (IRI) of each food item was derived from IRI $=(\mathrm{N}+$ P) $\times$ FO. Values of IRI were standardized in percentage following Cortés (1997).

To detect seasonal differences in prey consumption, we applied a cluster analysis (UPGMA) based on the Bray-Curtis similarity index, which varies from $0-1$, with 0 signaling no similarity between groups, and 1 meaning that the groups share all prey items consumed. These analyses were performed using the IRI values obtained for each food item from each season of the year. Subsequently, the significance of the groupings was tested with analysis of similarities (ANOSIM).

Trophic niche breadth was calculated for each season using Levin's standardized niche breadth index. The values vary between 0 and 1 ; values close to 0 represent narrow niches and values close to 1 indicates wide niches (Krebs 1999). Seasons are defined as follow: summer (January-March); autumn (April-June); winter (July-September); and spring (October-December). Analyses were performed using ECOSIN (Entsminger 2014).

\section{Results}

We sampled 101 Dendropsophus minutus, there were 89 adult males, 4 young males, 4 adult females and 4 juveniles of undetermined sex. SVLs range from $12.7-24.3 \mathrm{~mm}$, and BM from $0.09-1.15 \mathrm{~g}$. Of the 101 stomachs, 51 were excluded from the analyses because 13 were empty, 11 contained only plant material, and 27 contained digested items that could not be identified. The 50 stomachs examined were from adult males and contained exclusively arthropods of three different classes and 10 orders (Table 1).

The greatest diversity and abundance of prey items are from the Class Insecta; seven orders (Blattodea, Hemiptera, Orthoptera, Diptera, Coleoptera, Lepidoptera, and Hymenoptera) are represented. There are two orders (Acari and Araneae) of Arachnida and one order (Enterobryomorpha) of Collembola. Most of the prey items are from Araneae, Lepidoptera, and Diptera, which have higher NF, FO and IRI values (Table 1). The highest PW values occur in Lepidoptera, Blattodea, and Orthoptera. Acari, Enterobryomorpha, and Hymenoptera are characterized by smaller IRI\% values (Table 1).

Seasonal variation in prey items can be summarized as follow: Diptera, Lepidoptera, and Araneae had the highest IRI\% in the summer; Lepidoptera and Araneae predominated in the autumn and Araneae and Diptera in the winter, whereas Araneae had the highest value in the spring. Araneae had high IRIs in all seasons; in contrast, dipterans were poorly represented in the spring and lepidopterans were absent in the winter (Figure 1). The analysis of seasonal similarity of prey items indicated that the winter and spring diets were more similar to one another $(70 \%)$, than were summer and autumn $(58 \%)$, although the results of the groupings did not show significant values (ANOSIM; $p=0.58$ ) (Figure 2).

Niche breath seems to vary seasonally. The greatest niche breadth occurred in the spring, (Levin's Index $=0.717$ ), followed by summer (Levin's Index $=0.240$ ), winter (Levin's Index $=$ 0.043), and autumn (Levin's Index $=0.004$ ).

\section{Discussion}

Regional dietary differences observed Dendrosophuys minutus (e.g., richness of prey taxa 
Table 1. Food items found in stomachs of Dendropsophus minutus. NF, numerical frequency; FO, frequency of occurrence; W, weight; IRI, index of relative importance. Values are shown as percentages.

\begin{tabular}{llcccc}
\hline Class & Order & NF & FO (\%) & W (g) & IRI (\%) \\
\hline ARACHNIDA & Acari & 2.99 & 3.00 & 0.05 & 0.46 \\
& Araneae & 28.36 & 25.00 & 12.62 & 49.59 \\
ColLEMBOLA & Enterobryomorpha & 1.49 & 2.00 & 0.02 & 0.11 \\
INSECTA & Blattodea & 1.49 & 2.00 & 22.32 & 1.80 \\
& Hemiptera (Cicadomorpha and Fulgoromorpha) & 5.97 & 8.00 & 0.96 & 1.33 \\
& Orthoptera & 4.48 & 5.00 & 15.32 & 4.49 \\
& Diptera & 14.93 & 18.00 & 1.95 & 12.77 \\
& Coleoptera (Cucujiformia, Chrysomelidae) & 8.86 & 10.00 & 4.29 & 1.67 \\
& Lepidoptera & 8.96 & 10.00 & 33.36 & 19.20 \\
& Hymenoptera (Formicidae) & 1.49 & 2.00 & 0.02 & 0.11 \\
UnDETERMINED & & 20.98 & 15.00 & 9.09 & 8.47 \\
\hline
\end{tabular}

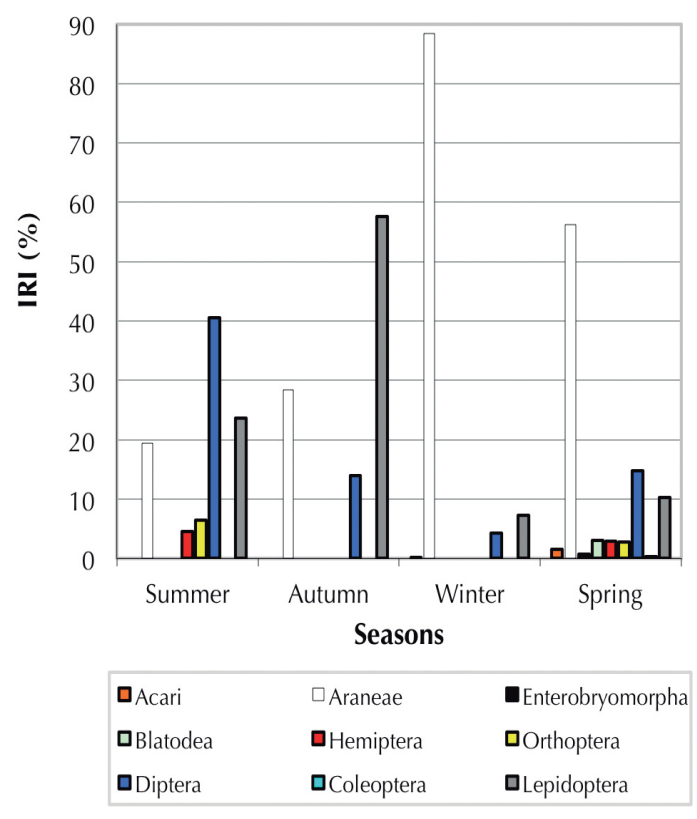

Figure 1. Seasonal analysis of the Dendropsophus minutus diet based on the Index of Relative Importance (IRI\%) of food items in the diet. and abundance of each prey taxon) may be related to the climatic and vegetation characteristics of the sites (Toft 1981, Toledo et al. 2007, Solé and Pelz 2007, Leivas et al. 2012a). Our results indicated that D. minutus in Ombrophilous Mixed Forest (southern Brazil) have a diet composed mainly of arthropods; this corroborates the findings of Van Sluys and Rocha (1998) and Santos et al. (2004) in the Ombrophilous Forest in the Amazon and in the Semi-deciduous Rainforest of northeastern Brazil, where there was a high frequency of arachnids in the diet.

The abundance and size of small prey items ingested may be associated with morphological characteristics of Dendropsophus minutus-i.e., owing to the small size of the frogs, they may select small-sized prey (Toledo et al. 2007) that are most abundant in the season (Toledo et al. 2007, Leivas et al. 2012a). The grouping winter-spring and summer-autumn similarity groupings of prey are not statistically significant because Araneae, Lepidoptera, and Diptera are 


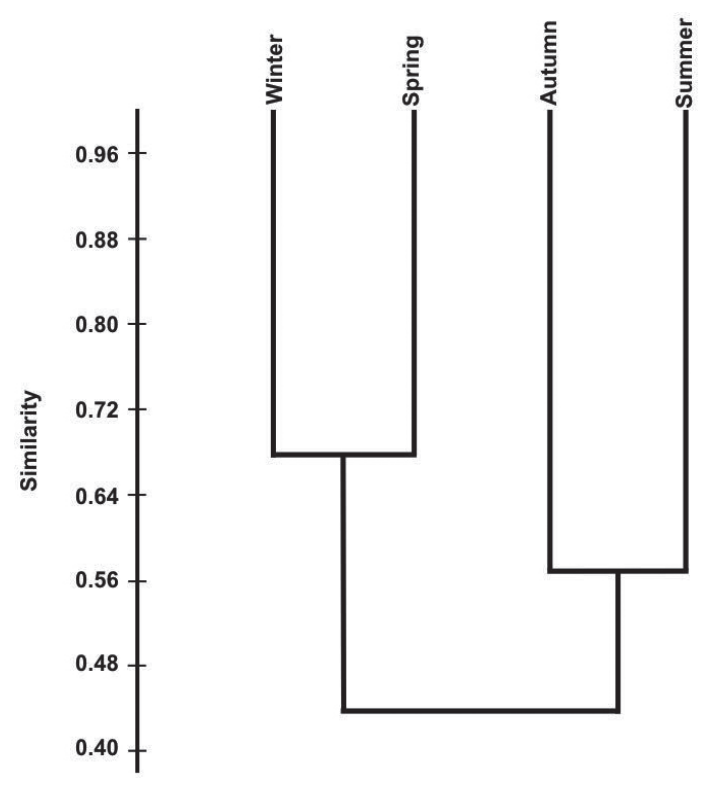

Figure 2. Analysis of seasonal similarity of prey items of Dendropsophus minutus with Bray-Curtis distance index.

predominant prey items all year long. However, the other food items were important determinants of seasonal variation in trophic niche breadth.

Because Dendropsophus minutus is a dietary generalist, it has a wide trophic niche (Van Sluys and Rocha 1998, Santos et al. 2004) and seasonal variation in the size of the trophic niche may be related to the reproductive process of the species. The most males with developed testes were found in the hottest periods of the year, spring and summer (Leivas et al. 2018); these are the seasons with the highest trophic niche-breadth values. Thus, food items with the lowest IRI supplement the diets of the frogs, and increase the available energy to them; this may be associated with greater reproductive process (Wells 2007, Leivas et al. 2012b). Moreover, a greater variety of food resources in spring and summer also may be advantageous for the successful development of postmetamorphic anurans (Leivas et al. 2012b).

\section{Acknowledgments}

Peterson T. Leivas and Tiago Burda received stipends for MSc research from the Coordenação de Aperfeiçoamento de Pessoal de Nível Superior (CAPES). The study was conducted under ICMbio permit number 10277-1.

\section{References}

Biavati, G. M., H. C. Wiederhecker, and G. R. Colli. 2004. Diet of Epipedobates flavopictus (Anura: Dendrobatidae) in a Neotropical Savanna. Journal of Herpetology 38: $510-518$.

Berazategui, M., A. Camargo, and R. Maneyro. 2007. Environmental and seasonal variation in the diet of Elachistocleis bicolor (Guérin-Méneville, 1838) (Anura: Microhylidae) from northern Uruguay. Zoological Science 24: 225-231.

Castro, D. P., M. J. Borges-Leite, D. C. Lima, and D. M. Borges-Nojosa. 2013. Parental care in two species of Leptodactylus Fitzinger, 1826 (Anura, Leptodactylidae) in north-eastern Brazil. Herpetology Notes 6: 267-269.

Cortés, E. 1997. A critical review of methods of studying fish feeding based on analysis of stomach contents: application to elasmobranch fishes. Canadian Journal of Fisheries and Aquatic Sciences 54: 726-738.

Crump, M. L. and N. J. Scott Jr. 1994. Visual encounter surveys. Pp. 84-92 in W. R. Heyer, M. A. Donnelly, R. W. McDiarmid, and M. S. Foster (eds.), Measuring and Monitoring Biological Diversity: Standard Methods for Amphibians. Washington. Smithsonian Institution Press.

Entsminger, G. L. 2014. EcoSim Professional: Null Modeling Software for Ecologists. Version 1. Acquired Intelligence Inc. and Pinyon Publishing. URL: http:// www.garyentsminger.com/ecosim/index.htm.

Frost, D. R. (ed.). 2017. Amphibian Species of the World: an Online Reference. Version 6.0 (01 December 2017). Electronic Database accessible at http://research.amnh. org/herpetology/amphibia/index.html. American Museum of Natural History, New York, USA. Captured on 10 January 2017.

Giasson, L. O. M. and C. F. B. Haddad. 2006. Social interactions in Hypsiboas albomarginatus (Anura: Hylidae) and the significance of acoustic and visual signals. Journal of Herpetology 40: 171-180.

Grayson, K. L., L. W. Cook, M. J. Todd, D. Pierce, W. A. Hopkins, R. E. Gatten Jr., and M. E. Dorcas. 2005. 
Effects of prey type on specific dynamic action, growth, and mass conversion efficiencies in the horned frog, Ceratophrys cranwelli. Comparative Biochemistry and Physiology 141: 298-304.

Krebs, C. J. 1999. Ecological Methodology. $2^{\text {nd }}$ Edition. Boston. Addison Wesley Educational Publishers. 624 pp.

Leivas, P. T., F. W. T. Leivas, and M. O. Moura. 2012a. Diet and trophic niche of Lithobates catesbeianus (Amphibia: Anura). Zoologia 29: 405-412.

Leivas, P. T., M. O. Moura, and L. F. Favaro. 2012b. The reproductive biology of the invasive Lithobates catesbeianus (Amphibia: Anura). Journal of Herpetology 46: $153-161$.

Leivas, P. T., T. B. Mayer, and L. F. Fávaro. 2018. The reproductive biology of Dendropsophus minutus (Amphibia: Anura) in South of Brazil. Herpetology Notes 11: 395-403.

López, J. A., P. A. Scarabotti, M. C. Medrano, and R. Ghirardi. 2009. Is the red spotted green frog Hypsiboas punctatus (Anura: Hylidae) selecting its preys? The importance of prey availability. Revista de Biologia Tropical 57: 847-857.

Maffei, F., F. K. Ubaid, and J. Jim. 2011. Anurofauna em área de cerrado aberto no município de Borebi, estado de São Paulo, Sudeste do Brasil: uso do habitat, abundância e variação sazonal. Biota Neotropical 11: 221-233.

Maneyro, R., D. E. Naya, I. Da Rosa, A. Canavero, and A. Camargo. 2004. Diet of the South American frog Leptodactylus ocellatus (Anura, Leptodactylidae) in Uruguay. Iheringia, Série Zoologia 94: 57-61.

Morais, A. R., R. P. Bastos, R. Vieira, and L. Signorelli. 2012. Herpetofauna da Floresta Nacional de Silvânia, um remanescente de Cerrado no Brasil Central. Neotropical Biology and Conservation 7: 114-121.

Miranda, T., M. Ebner, M. Solé, and A. Kwet. 2006. Spatial, seasonal and intrapopulational variation in the diet of Pseudis cardosoi (Anura: Hylidae) from the Araucária Plateau of Rio Grande do Sul, Brasil. South American Journal of Herpetology 1: 121-130.

Pacheco, E. O., V. G. Ferreira, and R. M. H. Carvalho. 2017. Diet of Boana albopunctata (Anura: Hylidae) in an
Atlantic Forest fragment of southeastern Brazil. Phyllomedusa 16: 57-62.

Peel, M. C., B. L. Finlayson, and T. A. McMahon. 2007. Updated world map of the Köppen-Geiger climate classification. Hydrology and Earth System Science 11: $1633-1644$

Santos, E. M., A. V. Almeida, and S. D. Vasconcelos. 2004. Feeding habits of six anuran (Amphibia: Anura) species in a rainforest fragment in Northeastern Brazil. Inheringia, Série Zoologia 94: 433-438.

Santos, L. R. S. and C. Oliveira. 2007. Morfometria testicular durante o ciclo reprodutivo de Dendropsophus minutus (Peters) (Anura, Hylidae). Revista Brasileira de Zoologia 24: 64-70.

Santos, L. R. S., L. Franco-Belussi, and C. Oliveira. 2012. Germ cell dynamics during the annual reproductive cycle of Dendropsophus minutus (Anura: Hylidae). Zoological Science 28: 840-844.

Solé, M. and B. Pelz. 2007. Do male tree frogs feed during the breeding season? Stomach flushing of five syntopic hylid species in Rio Grande do Sul, Brazil. Journal of Natural History 41: 2757-2763.

Toft, C. A. 1981. Feeding ecology of Panamanian litters anurans: patterns in diet and foraging mode. Journal of Herpetology 15: 139-144.

Toft, C. A. 1995. Evolution of diet specialization in poison dart frogs (Dendrobatidae). Herpetologica 51: 202-216.

Toledo, L. F., R. S. Ribeiro, and C. F. B. Haddad. 2007. Anurans as prey: an exploratory analysis and size relationships between predators and their prey. Journal of Zoology 271: 170-177.

Van Sluys, M. and C. F. D. Rocha. 1998. Feeding habits and microhabitat utilization by two syntopic Brazilian Amazonian frogs Hyla minuta and Pseudopaludicula sp. (gr. falcipes). Revista Brasileira de Biologia 58: 559562 .

Wells, K. D. 2007. The Ecology and Behavior of Amphibians. Chicago and London. The University of Chicago Press. $1400 \mathrm{pp}$.

Editor: Eduardo F. Schaefer 